\title{
TINDAK PIDANA KORUPSI YANG DILAKUKAN NOTARIS-PPAT DALAM MENJALANKAN KEWENANGAN JABATANNYA
}

\author{
Agus Santoso \\ Kantor Notaris-PPAT Sulasiyah Amini \\ Jalan Sulfat Nnomor 9 Malang \\ Email: agusdanrekan@gmail.com
}

\begin{abstract}
Abstrak
Pasal 15 Undang-Undang Nomor 2 tahun 2014 mengatur tentang semua kewenangan dari notaris untuk membuat ataupun mengkonstatir kepentingan para pihak dalam suatu akta autentik. Akta notaris merupakan akta otentik dimana notaris menerima data formil dari para pihak yang dijadikan alat bukti oleh para penyidik baik kepolisian maupun kejaksaan untuk melakukan penyidikan suatu perkara untuk mencari data materiel dalam suatu permasalahan hukum yang terjadi. Jika notaris tidak berhatihati, teliti dan memahami dampak hukum dalam pembuatan akta dan salah dalam membuatnya, 100 akta yang dibuat 99 benar dan 1 salah, maka akan menjeratnya dalam perkara hukum (korupsi). Keberadaan MKN yang menggantikan peran dari MPD dalam memberikan persetujuan atau menolak permintaan penyidik yang hendak memanggil dan memeriksa notaris dalam proses peradilan belum bisa banyak membantu untuk melindungi notaris dari jeratan hukum karena kedudukan atau upaya hukum dari MKN tidak diatur secara tegas dalam suatu peraturan perundangundangan. Notaris harus menerapkan prinsip kehatian-hatian dan menjaga kode etik dalam menjalankan kewenangan jabatannya dalam membuat akta otentik agar tidak terjerat tindak pidana korupsi.
\end{abstract}

Kata Kunci: korupsi, kewenangan, notaris, akta otentik

\section{Abstract}

Article 15 of Law Number 2 of 2014 regulates all authority of a notary to make or state interests of the parties in an authentic deed. Notary deed is an authentic deed in which the notary receives formal data from the parties that is used as evidence by investigators both the police and the attorney to conduct a case investigation to look for material data in a legal problem that occurs. If the notary is not careful, thorough and understands the impact of the law in making a deed and gets wrong in making it, 100 deeds made 99 right and 1 wrong, it will ensnare him in a legal case (corruption). The existence of MKN which replaces the role of MPD in giving approval or rejecting requests from investigators who want to summon and examine a notary in the judicial process has not been able to 
help much to protect the notary from legal snares because the position or legal remedy of the MKN is not explicitly regulated in a statutory regulation. . The notary must apply the precautionary principle and maintain the code of ethics in carrying out the authority of his position in making an authentic deed so that it is not caught in a criminal act of corruption.

Keywords: corruption, authority, notary, authentic deed

\section{PENDAHULUAN}

Notaris merupakan pejabat umum juga sering menjadi konsultan hukum yang diberi kewenangan atribusi oleh negara dalam membuat suatu akta autentik. Kewenangan-kewenangan Notaris diatur dalam Pasal 15 Undang-Undang Nomor 2 Tahun 2014 Tentang Perubahan Atas UndangUndang Nomor 30 Tahun 2004 Tentang Jabatan Notaris (selanjutnya disebut UUJN) yang berisi segala bentuk perbuatan, perjanjian, dan ketetapan yang diwajibkan oleh peraturan perundang-undangan dan/atau yang dikehendaki oleh para pihak yang berkepentingan untuk dikonstatirkan dalam sebuah akta otentik

Pada hakekatnya suatu akta autentik merupakan kebenaran data formil dari para pihak mengenai apa yang disampaikan kepada notaris untuk dimuat dalam sebuah akta. Akan tetapi, tidak semua keterangan yang diberikan oleh penghadap atau para pihak kepada notaris itu adalah kebenaran data sesungguhnya. Penghadap bisa saja mempunyai niat jahat dan/atau memanfaatkan kelengahan notaris dengan memberikan keteranganketerangan serta dokumen palsu kepada notaris. Akta autentik yang dibuat dan dihasilkan oleh notaris menjadi tidak benar, sehingga dapat menimbulkan kerugian kepada salah satu pihak. Apabila salah satu pihak sudah merasa dirugikan terhadap akta autentik tersebut, maka notaris dapat dianggap dan dituntut telah melakukan malpraktek, walaupun notaris dalam hal ini telah bekerja sesuai dengan kode etik kewenangan dalam membuat akta autentik. Dengan hal inilah yang menjadi dasar diperlukannya suatu perlindungan hukum yang benar bagi jabatan notaris.

Dengan semakin canggihnya terknologi dan era moderen saat ini perkembangan kejahatan didalam dunia hukum berkembang semakin pesat karena adanya suatu tujuan dan niat yang tidak baik diinginkan oleh pihakpihak tertentu. Kejahatan yang sering terjadi dalam dunia hukum salah satunya terjadi kepada jabatan notaris. Akhir-akhir ini semakin sering dipermasalahkan karena kewenanganya dalam membuat akta autentik yang dibuatnya terindikasi mengandung unsur-unsur tindak pidana, hal ini disebabkan karena kurang kehati-hatian notaris terhadap para pihak yang menghadap membuat akta autentik yang sering mengambil kesempatan 
demi keuntungannya sendiri atau salah satu pihak yang berkeinginan membuat akta dengan cara melakukan kejahatan seperti memberikan surat palsu dan/atau keterangan palsu bahkan menghilangkan data yang benar kedalam akta otentik yang dibuat oleh notaris.

Disamping itu didalam praktik, notaris seringkali karena lalai dan kurang teliti dalam melakukan pengecekan data formal pada instansi terkait sehingga bisa kemungkinan membuat akta autentik dalam satu objek lokasi yang sama. Demikian pula para penyidik kepolisian maupun kejaksaan harusnya dalam proses atau prosedur pemeriksaan dan pemanggilan juga harus menghormati kode etik jabatan notaris yang telah diangkat oleh Menteri Hukum dan HAM, seperti profesi atau jabatan hukum yang lain ketika melakukan malpraktek dalam kewenanganya.

Notaris masuk ke Indonesia dengan beradanya Vereenigde Oos Ind Compaigne (VOC) di Indonesia. Jan Pieterszoon yang saat itu merupakan Gubernur Jendral Jacatra (sekarang Jakarta) untuk keperluan para penduduk dan pedagang di Jacatra dianganggap perlu mengangkat seorang notaris (notarium publicum). Jan Pieterszoon mengangkat Melchior Kerchem sebagai Sekretaris College van Schepenen (Urusan Perkapalan Kota) untuk merangkap sebagai notaris yang berkedudukan di Jacatra. Dalam surat pengangkatanya yaitu melayani dan melakukan surat libel (smaadschirft), surat wasiat dibawah tangan (codicil), persiapan penerangan, akta perjanjian perdagangan, perjanjian kawin, surat wasiat (testament), dan akta-akta lainnya dan ketentuan-ketentuan yang perlu dari Kotapraja. ${ }^{1}$

Notaris ketika menjalankan praktik dalam kewenangan jabatannya yang seringkali terjadi, yaitu jika notaris tersangkut perkara pidana, dan akta notaris diindikasikan sebagai awal atau penunjuk terjadinya perkara pidana. Dalam hal ini penyidik tidak menilai bahwa akta notaris sebagai yang "apa adanya", tetapi akan mencari "ada apa" dibalik "apa adanya", atau dengan kata lain setiap penghadap yang datang ke notaris telah "benar berkata" dan kita tuangkan dalam bentuk akta, dan jika terbukti penghadap tidak "berkata benar" atau "ada yang tidak benar" sehingga menjadi "tidak berkata benar", maka hal tersebut oleh penyidik dapat menggiring notaris sebagai yang pihak "menyuruh melakukan" atau membatu melakukan" atau "turut serta melakukan" dan sebagai calon tersangka. Apakah dalam hal ini ada kesadaran bagi para notaris untuk "menyuruh melakukan" atau membatu melakukan" atau "turut serta melakukan" suatu tindak pidana bersama-sama dengan pihak yang bersangkutan? Sangatlah kecil kemungkinan notaris

\footnotetext{
${ }^{1}$ Habib Adjie, Hukum Notaris di Indonesia, (Bandung: PT Refika Aditama, 2014),
} hal 3. 
menyalah gunakan kewenangannya untuk menghancurkan diri sendiri dengan berbuat melanggar peraturan-peraturan atau kode etik yang ada. ${ }^{2}$

Penetapan tersangka oleh Kejari Kota Malang terhadap NotarisPPAT Natalia Christiana dalam penjualan tanah aset pemkot di Jalan BS Riadi, Oro-Oro Dowo, Kecamatan Klojen, Kota Malang, Jawa Timur yang dilakukan bersama Leonardo yang sudah ditetapkan sebagai tersangka dan sudah di tahan terlebih dahulu, menjadi kasus hangat dan perhatian di kalangan para Notaris-PPAT di Kota Malang. Natalia diduga terlibat dan mengetahui dan ikut serta jika sebenarnya aset tanah yang diurus merupakan aset milik Pemkot Malang. Dia tetap saja ikut memproses perubahan kepemilikan aset pemda itu sampai terbit Sertifikat Hak Milik (SHM). Bahkan dia diduga terlibat hingga konversi, pemecahan sertifkikat, membuatkan akta kuasa jual dan hibah-hibah palsu. Tersangka dikenakan Pasal 2 ayat 1, Pasal 3 junto Pasal 18 Undang-Undang Nomor 31 Tahun 1999 tentang Pemberantasan Tindak Pidana Korupsi sebagaimana diubah dan ditambah Undang-Undang Republik Indonesia Nomor 20 Tahun 2001 tentang Perubahan atas Undang-Undang Nomor 31 Tahun 1999 juncto Pasal 5 ayat 1 ke 1 (disebut UU Tipikor) dengan ancaman 20 tahun. $^{3}$

Dengan adanya pengembangan kasus tersebut, kepastian hukum Natalia yang sudah ditahan juga menjadi rumit karena penyidik masih mencari alat bukti dan pihak-pihak lain yang mungkin terlibat didalamnya. Akta autentik yang dibuat notaris harus mengandung syarat-syarat yang diperlukan agar tercapai sifat otentik dari akta itu misalnya dalam pembacaan akta para pihak harus menghadap dan menerangkan bahwa harus mencantumkan identitas para pihak, membuat isi perjanjian yang dikehendaki para pihak, menandatangani akta dan sebagainya. Tetapi apabila syarat-syarat itu tidak terpenuhi maka akta tersebut dapat dibatalkan atau batal demi hukum. Di dalam Undang-Undang yang terdahulu atau kolonial notaris merupakan seorang yang ditunjuk oleh negara untuk mengakomodir kepentingan para pihak dalam perkapalan atau bisnis dan negara sangat melindungi hak serta kewajibannya. Tidak seperti sekarang kewenangan notaris semakin banyak sehingga sangat rentan menyalahgunakan wewenang dan terkena perkara hukum jika tidak berhatihati dan teliti dalam menjalankan kewenanganya membuat akta autentik.

Dengan ditetapkannya Notaris-PPAT Natalia sebagai tersangka dalam perkara hukum pembuatan akta autentik perlu dipertanyakan prosedur pemanggilan dan perlindungan hukumnya. Apakah pihak Kejari Kota Malang sudah tepat dan sesuai. Karena dalam pemanggilan Notaris-PPAT

${ }^{2}$ Ibid, hal. 9 .

${ }^{3}$ http://wartahukum.net/2018/10/notaris-natalia-christiana-akhirnya-ditetapkansebagai-tersangka/, diakses pada tanggal 22 Nopember 2018, jam 22.45 WIB. 
sudah diatur dalam UUJN pasal 66 ayat 1 maupun aturan yang terbaru berupa Permen Hukum dan Hak asasi Manusia Republik Indonesia pasal 23 Nomor 7 Tahun 2016 tentang Majelis Kehormatan Notaris.

\section{METODE PENELITIAN}

Didalam melakukan penelitian ini jenis yang dipakai adalah penelitian yuridis empiris yang dengan cara lain adalah jenis penelitian hukum sosiologis dan/atau disebut pula dengan penelitian lapangan, yaitu mengkaji ketentuan hukum yang berlaku serta apa yang terjadi dalam fakta hukum atau kenyataannya yang ada di masyarakat. ${ }^{4}$ Dengan pengertian lain yaitu suatu penelitian yang dilakukan terhadap keadaan sesungguhnya atau keadaan nyata yang terjadi didalam masyarakat dengan maksud untuk mengetahui dan menemukan fakta-fakta baru dan data yang dibutuhkan, setelah data yang diperlukan terkumpul kemudian menuju kepada pencarian masalah yang pada akhirnya menuju pada penyelesaian masalah. Jenis penelitian ini dipilih agar dalam penelitian yang dilakukan bisa secara efektif menunjukkan bagaimana antara kenyataan dari permasalahan yang telah ada dengan bagaimana seharusnya menurut peraturan perundangundangan yang berlaku.

Pendekatan yang dipakai pada penelitian jenis ini adalah pendekatan sosiologis. Pendekatan yuridis sosiologis adalah mencari dan menemukan konsep hukum sebagai lembaga sosial yang sosiologis dan berfungsi baik dalam sistem kehidupan nyata. ${ }^{5}$

Didalam pendekatan ini menitik beratkan penelitian yang bertujuan untuk mendapatkan pengetahuan hukum secara yuridis sosiologis artinya peraturan perundang-undangan yang telah mengatur kewenangan jabatan notaris yang berkaitan dengan pembuatan akta sudah dianggap sebagai suatu harapan (das sollen) apakah sudah sesuai dengan kenyataannya (das sein). Bagaimana semestinya seorang Notaris-PPAT menjalankan kewenanan jabatanya. Dalam hal ini dapat dikaji secara lebih mendalam. Dengan cara melakukan wawancara kepada Notaris yang bersangkutan, 2 (dua) karyawan Notaris yang bersangkutan, Polres Kota Malang dan Kejaksaan Negeri Kota Malang.

Cara lain pendekatan ini menggunakan peraturan perundangundangan (statue approach) yang dilakukan dengan mengtahui semua peraturan perundang-undangan yang berkaitan terhadap masalah penelitian yang akan diteliti, yaitu terkait peraturan perundang-undangan yang

${ }^{4}$ Bambang Waluyo, Penelitian Hukum dalam Praktek, (Jakarta: Sinar Grafika, 2002), hal.15.

${ }^{5}$ Soerjono Soekanto, Pengantar Penelitian Hukum, (Jakarta: Universitas Indonesia Press, 1986), hal.51. 
mengatur tentang kewenangan jabatan notaris berkaitan dengan pembuatan akta.

\section{PEMBAHASAN}

\section{Perlindungan Hukum Terhadap Notaris-PPAT}

Untuk dapat mempelajari serta mengetahui dengan jelas bagaimana Peraturan Perundang-Undangan Jabatan Notaris bisa melindungi seorang Notaris-PPAT ketika ditetapkan sebagai tersangka oleh Kejaksaaan Negeri. Penulis dengan ini membuat sebuah tabel untuk membandingkan kewenangan dari mulai sebelum kemerdekaan Republik Indonesia sampai dengan saat ini yang tertuang dalam Peraturan Perundang-Undangan Jabatan Notaris yang telah berlaku dan disahkan oleh negara.

\section{Tabel 1: Perbandingan Kewenangan Notaris}

\begin{tabular}{|c|c|c|c|}
\hline \multicolumn{4}{|c|}{ Berdasarkan } \\
\hline No & Stb & $\begin{array}{l}\text { Pasal } 15 \text { Undang-Undang } \\
\text { Nomor } 30 \text { Tahun } 2004\end{array}$ & $\begin{array}{l}\text { Pasal } 15 \text { Undang-Undang } \\
\text { Nomor } 2 \text { Tahun } 2014\end{array}$ \\
\hline 1 & 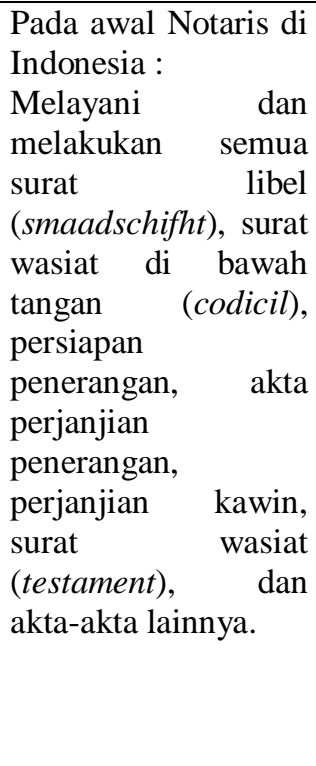 & $\begin{array}{l}\text { Ayat 1 (satu) : } \\
\text { Membuat akta otentik } \\
\text { mengenai semua perbuatan } \\
\text { perjanjian, ketetapanyang } \\
\text { diharuskan oleh peraturan } \\
\text { perundang-undangan yang } \\
\text { di kehendaki oleh yang } \\
\text { berkepentingan, menjamin } \\
\text { kepastian } \\
\text { pembuatan tanggal } \\
\text { menyimpan } \\
\text { memberikan grose, salinan } \\
\text { dan kutipan akta sepanjang } \\
\text { pembuatan akta itu tidak } \\
\text { tidak juga ditugaskan atau } \\
\text { dikecualikan kepada pejabat } \\
\text { lain atau orang lain yang } \\
\text { ditetapkan oleh undang- } \\
\text { undang. }\end{array}$ & $\begin{array}{l}\text { Ayat 1 (satu): } \\
\text { Membuat akta autentik } \\
\text { mengenai semua perbuatan } \\
\text { perjanjian, penetapan, } \\
\text { perjanjian, dan penetapan } \\
\text { sesuai peraturan perundang- } \\
\text { undangan yang di kehendaki } \\
\text { oleh yang berkepentingan, } \\
\text { menjamin kepastian tanggal } \\
\text { pembuatan akta, menyimpan } \\
\text { akta, memberikan grose, } \\
\text { salinan dan kutipan akta } \\
\text { sepanjang pembuatan akta } \\
\text { itu tidak tidak juga } \\
\text { ditugaskan atau } \\
\text { dikecualikan kepada pejabat } \\
\text { lain atau orang lain yang } \\
\text { ditetapkan oleh undang- } \\
\text { undang. }\end{array}$ \\
\hline 2. & $\begin{array}{l}\text { Stb no.11 pasal 1 } \\
\text { Membuat akta-akta } \\
\text { dan kontrak-kontrak } \\
\text { dengan maksud } \\
\text { untuk memberikan } \\
\text { kepadanya kekuatan } \\
\text { dan pengesahan, } \\
\text { menetapkan dan }\end{array}$ & $\begin{array}{l}\text { Ayat } 2 \text { (dua): } \\
\text { 1. Mengesahkan tanda } \\
\text { tangan dan menetapkan } \\
\text { kepastian tanggal surat } \\
\text { dibawah tangan dengan } \\
\text { mendaftar dalam buku } \\
\text { khusus } \\
\text { 2. } \text { Membukukan surat }\end{array}$ & $\begin{array}{l}\text { Ayat } 2 \text { (dua): } \\
\text { 1. } \text { Mengesahkan tanda } \\
\text { tangan dan menetapkan } \\
\text { kepastian tanggal surat } \\
\text { dibawah tangan dengan } \\
\text { mendaftar dalam buku } \\
\text { khusus } \\
\text { 2. } \text { Membukukan surat }\end{array}$ \\
\hline
\end{tabular}




\begin{tabular}{|c|c|c|c|}
\hline & $\begin{array}{l}\text { memastikan } \\
\text { tanggalnya, } \\
\text { menyimpan asli atau } \\
\text { minutanya dan } \\
\text { mengeluarkan } \\
\text { grossenya, } \\
\text { memberikan salinan } \\
\text { yang sah dan benar. }^{6}\end{array}$ & $\begin{array}{l}\text { dibawah tangan dengan } \\
\text { mendaftar dalam buku } \\
\text { khusus } \\
\text { 3. Membuat kopi dari asli } \\
\text { surat di bawah tangan } \\
\text { berupa salinan yang } \\
\text { memuat uraian } \\
\text { sebagaimana ditulis dan } \\
\text { digambarkan dalam } \\
\text { surat yang bersangkutan } \\
\text { 4. Melakukan pengesahan } \\
\text { kecocokan fotokopi } \\
\text { dengan surat lainnya } \\
\text { 5. Memberikan hukum } \\
\text { penyuluhan dengan } \\
\text { sehubungan an ang } \\
\text { pembuatan akta } \\
\text { Membuat akta yang } \\
\text { berkaitan dengan } \\
\text { pertanahan risalah } \\
\text { 7. Membuat akta } \\
\text { lelang }\end{array}$ & $\begin{array}{l}\text { dibawah tangan dengan } \\
\text { mendaftar dalam buku } \\
\text { khusus } \\
\text { 3. Membuat kopi dari asli } \\
\text { surat di bawah tangan } \\
\text { berupa salinan yang } \\
\text { memuat uraian } \\
\text { sebagaimana ditulis dan } \\
\text { digambarkan dalam } \\
\text { surat yang bersangkutan } \\
\text { 4. Melakukan pengesahan } \\
\text { kecocokan fotokopi } \\
\text { dengan surat lainnya } \\
\text { 5. Memberikan hukum } \\
\text { penyuluhan dengan } \\
\text { sehubungan an den } \\
\text { pembuatan akta } \\
\text { 6. Membuat akta yang } \\
\text { berkaitan dengan } \\
\text { pertanahan an risalah } \\
\text { 7. Membuat akta } \\
\text { lelang }\end{array}$ \\
\hline 3. & & $\begin{array}{l}\text { Ayat 3 (tiga): } \\
\text { Selain kewenangan diatas } \\
\text { Notaris mempunyai } \\
\text { kewenangan lain yang } \\
\text { diatur dalam peraturan } \\
\text { perundang-undangan }\end{array}$ & $\begin{array}{l}\text { Ayat } 3 \text { (tiga): } \\
\text { 1. Mensertifikasi transaksi } \\
\text { yang dilakukan secara } \\
\text { elektronik } \\
\begin{array}{l}\text { notary) } \\
\text { 2. }\end{array} \\
\begin{array}{l}\text { Membuat akta ikrar } \\
\text { wakaf }\end{array} \\
\text { 3. } \begin{array}{l}\text { Membuat akta Hipotek } \\
\text { pesawat terbang. }\end{array}\end{array}$ \\
\hline
\end{tabular}

Sumber: data sekunder yang telah diolah

Berdasarkan data tabel perbandingan kewenangan-kewenangan notaris diatas dapat penulis simpulkan bahwa kewenangan yang dimiliki notaris dari zaman sebelum kemerdekaan (staatblad) dan kemudian setelah merdeka (UUJNP) menjadi bertambah semakin banyak sehingga terlalu banyak kewenangan terdapat pula celah hukum untuk ditetapkan sebagai tersangka pidana juga semakin banyak. Resiko dan tanggungjawab dalam menjalankan kewenangan jabatan Notaris bila salah dalam mengambil keputusan dalam membuat akta dapat menjadi masalah di kemudian hari. Didalam praktik permasalahan hukum yang sering terjadi tidak datang

\footnotetext{
${ }^{6}$ Habib Adjie, Op.Cit, hal, 4.

${ }^{7}$ Undang-Undang Nomor 30 tahun 2004 Tentang Jabatan Notaris.

${ }^{8}$ Habib Adjie, Penafsiran Tematik Hukum Notaris di Indonesia, (BandungL PT
} Refika Aditama, Bandung), hal,1-2. 
langsung pada waktu terjadinya pembuatan akta otentik melainkan bergulirnya waktu yang lama atau terdapat sengketa atau permasalahan dari para pihak dalam isi akta yang dibuat oleh dan dihadapan Notaris.

Penetapan tersangka tindak pidana korupsi oleh Kejari Kota Malang yang terjadi kepada Natalia, karena notaris kurang teliti dan berhati-hati dalam melakukan pengecekan data formal dan menjaga kode etik dalam menjalankan kewenanganya didalam membuat akta otentik. Bagaimana bisa Natalia dengan dasar atau surat tanah dalam satu objek lokasi yang sama bisa dibuatkan 2 (dua) akta autentik yang merupakan bentuk peralihan tanah oleh para pihak di dalam akta yang menjadikan sengketa dalam waktu 1 tahun berikutnya.

Berdasarkan fakta yang ada dan diperoleh, dibuatkan 2 akta autentik peralihan hak tanah menjadi 2 (dua) dalam satu lokasi yang sama yaitu :

1. Untuk SK no.593/1/255/428.114 tahun 2001 tertulis atas nama Misrinah Soetjipto berdasarkan akta Notaris yang dibuat oleh Natalia Christina dialihkan kepada Hendrardi Gunawan, Sarjana Hukum dari ahli waris almarhumah Misrinah.

2. Sertifikat Hak Milik nomor: 1607/Oro-oro dowo tertulis atas nama:

1. Mulyani Rinah

2. Mukti Nasiti

3. Ines Gunung Sri Wahyuni

4. Nurtekad Sambodo

5. Insinyur Yohanes Susilo Agung.

Berdasarkan data yang ada Sertifikat Hak Milik nomor: 1607/OroOro Dowo merupakan hasil pemecahan dari Sertifikat Hak Milik nomor: 1603/Oro-Oro Dowo yang dimana diperoleh dari proses konversi (permohonan Hak) dimana ada beberapa langkah untuk menjadikan tanah dari aset Pemerintah Kota Malang menjadi hak yasan / verponding menjadi sebuah sertifikat hak milik yang diketahui dilakukan saudara leonardo dengan bekerjasama dengan pihak kelurahan setempat. Natalia tidak mengetahui asal usul tanah SHM 1607/Oro-Oro Dowo yang telah dibawa ke kantor notaris. Prosedur yang dilakukan oleh Natalia sudah benar karena sudah melakukan pengecekan sertifikat di Kantor Pertanahan Kota Malang dan dinyatakan bersih kemudian dilanjutkan membuat akta notaris dan beberapa akta lainnya.

Disamping itu notaris sebagai pejabat yang ahli dalam bidang hukum sering menjadi konsultan hukum bagi para pihak yang datang ke kantor notaris. Disisi lain dengan adanya konsultasi hukum tersebut notaris bisa terseret dalam dakwaan turut serta dan hadir dalam pembuatan akta yang cacat hukum. Para penyidik dengan mudah mengambil analisa hukum karena mereka mencari data material dalam menjalankan penyidikan dalam 
perkara tersebut. Sedangkan notaris hanya menerima data formal dan sudah dilakukan pengecekan pada intansi yang terkait seperti sertifikat hak milik yang sudah dilakukan pengecekan pada Kantor Pertanahan Kota Malang dan sesuai prosedur yang berlaku. Menjadi aneh disini jika pihak yang mengeluarkan data atau instansi yang terkait dalam pengecekan sertifikat tanah bersih (tidak terblokir) malah tidak tersangkut perkara hukum.

Didalam Pasal 2 ayat 1 junto Pasal 3 Undang-Undang Tipikor tidak tepat rasanya untuk dijadikan dasar petetapan tersangka kepada Natalia karena melakukan tindak pidana korupsi oleh Kejari Kota Malang. Karena Natalia disini sudah sesuai prosedur dalam pembuatan akta dan melakukan pengecekan pada instansi terkait. Notaris yang tidak mengolah keuangan negara secara langsung tidak bisa dikatakan korupsi, kalaupun ada permasalahan hukum seharusnya sanksi administratif baik sidang kode etik jabatan Notaris ataupun ada ganti kerugian ketika ada salah satu pihak merasa dirugikan. Para penyidik dari kepolisian maupun kejaksaan harusnya tetap menghormati jabatan notaris yang menjalankan sebagian kepentingan negara dalam pembuatan akta dengan melakukan prosedur pemanggilan notaris sesuai peraturan perundang-undangan yang berlaku.

Di dalam penerapan teori hukum fungsional tujuannya lebih terfokus pada keterkaitan kewenangan dan fungsi dari penyidik kepolisian serta kejaksaan diharapkan sesuai dengan peraturan perundang-undangan. Apabila menganalisis dengan teori ini, hukum dilihat dari aspek fungsi atau kegunaanya. Para hakim atau pembentuk undang- undang dalam menjalankan perannya masing-masing harus memberikan manfaat atau kegunaan bagi masyarakat banyak (notaris).

Dengan adanya penetapan tersangka oleh Kejari Kota Malang, jabatan Natalia sebagai notaris yang sudah lama dijalankan menjadi jelek dan mengalami stigma negatif (labelling theory) oleh masyarakat. Setelah adanya kejadian perkara hukum tersebut kantor notaris yang dulu ramai menjadi sepi dan hampir tidak ada aktifitas lagi. Peran notaris hanyalah sebagai media untuk lahirnya suatu akta autentik, notaris bukan pihak dalam akta yang dibuatnya, sehingga hak dan kewajiban hukum yang dilahirkan dari perbuatan hukum yang disebutkan dalam akta notaris tersebut, hanya mengikat para pihak dalam akta itu. Jika terjadi sengketa mengenai isi perjanjian tersebut, maka notaris tidak terlibat dalam pelaksanaan kewajiban untuk dituntut suatu hak, karena notaris berada diluar perbuatan hukum pihak-pihak tersebut. Hal tersebut terjadi apabila notaris telah bekerja atau menjalankan tugas jabatannya sesuai dengan Undang-Undang serta telah sesuai dengan kode etik notaris.

Apabila notaris bekerja tidak sesuai dengan standar profesinya atau melanggar ketentuan-ketentuan dalam proses pembuatan akta autentik, 
maka notaris tersebut dapat dikenakan sanksi yang berupa sanksi administrasi, sanksi perdata dan sanksi pidana. Notaris dapat diberikan sanksi administrasi, apabila Notaris tersebut terbukti telah melanggar ketentuan-ketentuan etika profesinya yang telah diatur di dalam UUJN maupun dalam kode etik notaris. Sanksi administrasi dapat diberikan secara berjenjang, mulai dari teguran lisan, teguran tertulis, pemberhentian sementara, pemberhentian dengan hormat hingga pemberhentian tidak hormat sebagaimana yang diatur dalam Pasal 85 UUJN.

Sanksi perdata dapat diberikan kepada notaris apabila pelanggaran yang dilakukan oleh notaris sehingga mengakibatkan kerugian bagi para pihak atau salah satu pihak terkait dengan pelaksanaan akta notaris tersebut, maka terhadap akta tersebut dapat diturunkan (didegradasi) kekuatan pembuktiannya menjadi akta dibawah tangan. Atas dasar tersebut, maka dapat menjadi alasan bagi para pihak yang menderita kerugian untuk menuntut penggantian biaya, ganti rugi dan bunga kepada notaris. Selain sanksi administrasi dan sanksi perdata, apabila terjadi pelanggaran terhadap pembuatan akta otentik, notaris juga dapat dikenakan sanksi pidana. Dalam prnaktek, banyak akta notaris dipermasalahkan oleh para pihak atau pihak lainnya dan sering pula notaris ditarik sebagai pihak yang turut serta melakukan atau membantu melakukan suatu tindak pidana terkait dengan akta yang dibuat oleh notaris, misalnya, notaris diduga telah melakukan pemalsuan surat atau Notaris dituduh telah memasukkan keterangan palsu ke dalam akta autentik (Pasal 264 KUHP).

Notaris sebagai pejabat umum dalam membuat akta autentik harus selalu memperhatikan standarisasi atau ketentuan-ketentuan dari suatu akta otentik, selain itu Notaris juga harus selalu berpijak pada aturan-aturan hukum yang berlaku (UUJN dan kode etik notaris). Apabila semua ketentuan tersebut telah dipenuhi, maka notaris tersebut dapat dipastikan bebas dari segala macam bentuk tuntutan yang diajukan kepadanya. Tetapi tidak kemungkinan para penyidik baik pada kepolisian maupun kejaksaan masih berusaha mencari celah terhadap setiap kesalahan kecil para notaris.

UUJN telah menempatkan notaris sebagai pejabat umum, yang menjalankan tugas sebagai jabatan, karena itu perlu mendapatkan perlindungan hukum adalah notaris sebagai jabatan, bukan notaris sebagai pribadi. Perlindungan hukum atas hak notaris merupakan hasil transformasi kepentingan yang dilakukan melalui proses legislasi dalam menjaga pembentuk hukum atau parlemen, sehingga hak notaris dapat dihormati atau dilindungi dan dipatuhi.

UUJN telah mengatur bahwa ketika notaris dalam menjalankan kewenangan jabatanya terbukti melakukan pelanggaran, notaris dapat dikenai dan dijatuhi sanksi, berupa sanksi perdata, administasi dan kode etik 
jabatan notaris dan sanksi-sanksi tersebut telah diatur baik sebelumnya dalam PJN, dan sekarang dalam UUJN dan kode etik jabatan tidak mengatur adanya sanksi pidana pada notaris. Dalam praktik ditemukan kenyataan bahwa suatu tindakan hukum atau pelanggaran yang dilakukan notaris sebenarnya dapat dijatuhi sanksi administrasi tapi kemudia ditarik atau dikualifikasikan sebagai suatu tindak pidana yang dilakukan oleh notaris. Pengkualifikasikan tersebut berkaitan dengan aspek-aspek seperti:

1. Kepastian hari, tanggal, bulan, tahun dan pukul menghadap;

2. Pihak (siapa-orang) yang menghadap notaris;

3. Tanda tangan yang menghadap;

4. Salinan akta tidak sesuai dengan minuta akta;

5. Salinan akta ada, tanpa dibuat minuta akta, dan;

6. Minuta akta tidak ditandatangani secara lengkap, tapi minuta akta dikeluarkan. ${ }^{9}$

UUJN telah mengatur bentuk perlindungan hukum yang dapat diberikan kepada Notaris dalam menjalankan tugas jabatannya sebagai pejabat umum, hal ini tercermin dalam Pasal 66 ayat (1) UUJN yang menyatakan, bahwa untuk kepentingan proses peradilan, penyidik, penuntut umum, atau hakim dengan persetujuan Majelis Kehormatan Notaris (MKN) berwenang:

a) Mengambil fotokopi minuta akta dan/atau surat-surat yang dilekatkan pada minuta akta atau protokol notaris dalam penyimpanan notaris, dan;

b) Memanggil notaris untuk hadir dalam pemeriksaan yang berkaitan dengan akta atau protokol notaris yang berada dalam penyimpanan notaris.

Dalam pemahaman perlindungan hukum terhadap notaris yang tercantum dalam Pasal 66 UUJN ini harus termasuk di dalamnya notaris pengganti, pejabat sementara notaris dan notaris emeritus atau werda notaris, karena dalam praktik masih sering dilakukan pemanggilan (pemeriksaan) kepada notaris yang sudah berhenti menjabat sebagai notaris untuk diperiksa oleh penyidik terkait dengan akta-akta yang pernah dibuatnya semasa masih menjabat sebagai notaris. Diharapkan dengan adanya UUJN ini keberadaan MKN dapat memberikan perlindungan hukum bagi semua orang yang (pernah) menjalankan tugas jabatan sebagai notaris.

UUJN telah mengatur mengenai perlindungan hukum terhadap Jabatan Notaris yang dilakukan oleh MKN, sebagaimana yang diatur dalam Pasal 66 ayat (1) UUJN, yang menyatakan bahwa untuk kepentingan proses peradilan, yakni penyidik, penuntut umum maupun hakim, yang hendak

${ }^{9}$ Habib Adjie, Op.Cit, hal, 25. 
memanggil notaris harus mendapat persetujuan terlebih dahulu dari MKN. Apabila terjadi kasus terkait dengan adanya dugaan malpratek yang dilakukan oleh Notaris dalam proses pembuatan akta otentik yang menyebabkan kerugian bagi salah satu pihak dalam akta yang dibuatnya, maka dalam hal ini ada beberapa langkah-langkah yang harus dipatuhi bagi penyidik maupun MKN, guna menjamin kepastian dan perlindungan hukum bagi pihak-pihak yang terkait, yaitu:

1. Penyidik, penuntut umum, maupun hakim untuk kepentingan proses peradilan dapat mengambil fotokopi minuta akta dan/atau surat-surat yang dilekatkan pada minuta akta atau protokol notaris dalam penyimpanan notaris dengan mengajukan permohonan tertulis kepada $\mathrm{MKN}$, dan permohonan tersebut juga disampaikan kepada notaris yang bersangkutan;

2. MKN berwenang melakukan pemeriksaan terhadap notaris yang dilaporkan telah melakukan tindak pidana dalam proses pembuatan akta.

3. MKN dapat memberikan persetujuan kepada penyidik, penuntut umum maupun hakim apabila notaris yang bersangkutan terbukti telah melakukan pelanggaran tindak pidana dalam proses pembuatan akta.

4. Apabila MKN tidak menemukan adanya bukti pelanggaran terkait dengan adanya dugaan tindak pidana yang dilakukan oleh notaris tersebut, maka dalam hal ini MKN tidak dapat memberikan persetujuan bagi penyidik yang hendak memanggil Notaris tersebut.

5. Jangka waktu bagi MKN dalam memberikan persetujuan atau tidak memberikan persetujuan secara tertulis kepada penyidikdalah 30 hari sejak diterimanya surat permohonan dari penyidik (Pasal 66 ayat (3) UUJN-P). Apabila dalam jangka waktu tersebut MKN tidak memberikan jawaban, maka MKN dianggap telah memberikan persetujuan (Pasal 66 ayat (4) UUJN).

Mengenai keberadaan MKN sebaiknya dibentuk di tingkat kabupaten atau kota (daerah), hal ini bertujuan untuk menghindari penumpukan perkara yang masuk dan harus diselesaikan melalui MKN. Apabila lembaga pengawas ini ditempatkan di kabupaten atau kota, maka lembaga MKN dapat dengan cepat tanggap dapat memberikan keputusan untuk menyetujui atau menolak permintaan dari penyidik terkait dengan pengambilan fotokopi minuta akta atau pemanggilan notaris itu sendiri untuk kepentingan proses peradilan. Hal ini dikarenakan UUJN hanya memberikan waktu 30 hari untuk memberikan putusan tersebut. Apabila tidak ada jawaban dalam rentang waktu itu, MKN dianggap menyetujui permintaan tersebut.

Apabila MKN memberikan persetujuan bagi penyidik untuk memanggil notaris untuk diperiksa, maka dalam hal ini Notaris tersebut 
dapat melakukan upaya hukum banding ke Pengadilan Tata Usaha Negara (PTUN). Hal tersebut dilakukan karena MKN yang berkedudukan sebagai badan atau jabatan Tata Usaha Negara dan telah mengeluarkan keputusan sebagai suatu keputusan Tata Usaha Negara sebagai hasil akhir dari pemeriksaan. Terhadap tindakan MKN yang memutuskan untuk menyetujui atau tidak menyetujui notaris untuk diperiksa oleh pihak lain sebagai pelaksanaan Pasal 66 UUJN, maka dalam hal ini, notaris atau penyidik yang merasa dirugikan terhadap keputusan MKN tersebut, dapat menempuh upaya hukum ke PTUN. Jadi berdasarkan uraian diatas, dengan adanya suatu prosedur khusus, serta ruang lingkup kewenangan yang jelas dari lembaga MKN, diharapkan MKN dapat memberikan suatu kejelasan dalam memberikan perlindungan hukum bagi institusi notaris, dan dapat mempertegas keberadaan dari lembaga MKN tersebut. Hal ini juga bertujuan agar institusi notaris tidak mudah disalahkan oleh pihak lain terkait dengan akta yang dibuat oleh notaris.

\section{Faktor-faktor yang Membuat Notaris-PPAT Bisa Ditetapkan Sebagai Tersangka Tindak Pidana Korupi}

1. Kurangnya penerapan prinsip kehati-hatian notaris dalam pembuatan akta autentik

Notaris dalam menjalankan kewenangan jabatannya dipandang sebagai seseorang yang diberi amanah oleh para pihak dan keteranganketerangannya dapat diandalkan serta dapat dipercayai yang tanda tangannya serta segel (capnya) memberi jaminan dan bukti kuat dalam akta autentik yang dibuatnya. ${ }^{10}$ Namun pada saat ini sering terjadi permasalahan hukum dalam pembuatan akta yang dibuat oleh notaris, karena akta yang dibuatnya terindikasi mengandung unsur-unsur tindak pidana karena pihak-pihak yang menghadap dalam proses pembuatan akta memberikan dokumen-dokumen atau surat palsu serta mencantumkan keterangan palsu kedalam akta otentik yang telah dibuat oleh notaris.

Dalam pencegahannya notaris yang terjerat dalam permasalahan hukum, adapun bentuk-bentuk prinsip kehati-hatian yang perlu dilaksanakan oleh notaris dalam proses pembuatan akta meliputi :

a. Melakukan pengenalan terhadap identitas penghadap

Dalam menjalankan tugasnya Notaris sebelum memulai membuat akta tentunya dihadapkan oleh para pihak yang ingin membuat akta otentik, tentunya notaris sebelum memasukan identitas para pihak

${ }^{10}$ Maria S.W. Sumardjono, Kebijakan Pertanahan Antara Regulasi dan Implementasi, (Jakarta: Kompas, 2001), hal. 14. 
kedalam suatu akta, notaris harus mengecek identitas para pihak seperti KTP, KK, atau paspor serta menyocokan foto pemilik identitas dengan pihak-pihak yang membuat akta autentik, agar mencegah pemalsuan identitas terhadap akta yang dibuat oleh notaris

b. Melakukan verifikasi atau pengecekan pada intansi terkait secara cermat data subyek dan obyek penghadap.

Maksud dan tujuan melakukan verifikasi adalah memeriksa data-data subyek dari para pihak apakah berwenang dan cakap atau tidak dalam melakukan perbuatan hukum sehingga dapat memenuhi syarat sahnya dari suatu akta seperti, apakah pihak yang bertindak sudah berurumur minimal 18 Tahun atau telah menikah menurut Pasal 39 ayat 1 huruf a UUJN. Sedangkan bagian dari proses memvalidasi data obyek adalah merupakan bagian proses dalam memeriksa dokumen-dokumen obyek yang dibawa oleh penghadap contohnya melakukan pengecekan sertifikat tanah ke Badan Pertanahan Nasional apakah sertifikat tersebut merupakan sertifikat asli atau palsu atau memang benar atau tidak yang bersangkutan (penghadap) yang memiliki sertifikitat tersebut.

c. Memberikan tenggang waktu dalam pengerjaan akta autentik.

Dalam mengerjakan suatu akta agar menghasilkan akta yang baik benar secara hukum, notaris memberikan tenggang waktu dalam proses pembuatan akta agar tidak terburu-buru dan dapat bekerja secara cermat serta teliti sehingga tidak menimbulkan kesalahan dalam pengerjaan akta notaris.

d. Bertindak hati-hati, cermat dan teliti dalam proses pembuatan akta.

Bertindak berhati-hati, cermat dan teliti dalam proses pembuatan akta kata-kata yang dituangkan ke dalam akta, karena dalam pelaksanaanya sangat sering terjadi akta yang dibuat notaris sering dipermasalahkan karena kata-kata yang dibuat tidak jelas atau menimbulkan penafsiran ganda.

e. Memenuhi segala syarat teknik pembuatan akta notaris untuk membuat akta notariil yang jauh dari indikasi permasalahan hukum tentunya notaris harus memenuhi syarat formal dan syarat materil dari pembuatan akta notaris berdasarkan UUJN ketentuan mengenai syarat formal dalam pembuatan akta diatur dalam Pasal 38 UUJN, sedangkan syarat materil yang harus dipenuhi dalam pembuatan akta otentik diatur dalam pasal $1320 \mathrm{KUH}-$ Perdata.

f. Melaporkan kepada pihak yang berwajib apabila terjadi indikasi pencucian uang dalam transaksi di kantor notaris.

2. Kedekatan emosional antara notaris dan para pihak (klien) 
Notaris menjalankan jabatannya, sering berurusan dan menerima berkas (klien) dari saudara, teman, maupun sahabat baik bahkan sudah menjadi langganan selama bertahun-tahun dan keluar masuk kantor notaris dengan biasanya. Disinilah terdapat celah jika notaris kurang berhati-hati dan teliti dalam membuat akta dari para pihak yang datang ke kantor notaris. Dalam kasus ini saudara leonardo merupakan klien tetap dan sering keluar masuk pada kantor Natalia datang untuk membuat akta. Tanpa rasa curiga kebiasaan notaris jika salah satu pihak tidak bisa hadir maka akta yang sudah ditandatangani para pihak sebelumnya dibawa oleh klien yang sudah langganan (leonardo) untuk dimintakan tanda tangan. Disinilah celah hukum terjadi apakah memang benar jika klien yang mewakili notaris dalam meminta tanda tangan pihak yang tidak hadir benar-benar melakukannya. Pada fakta yang terjadi ada salah satu pihak yang meninggal dan ikut tanda tangan dalam akta notaris. Faktor kedekatan emosional inilah menjadi sangat rentan notaris terjerat perkara hukum karena kepercayaan yang sudah terjalin sejaklama di salah gunakan oleh klien dalam menjalankan amanah yang diberikan. Notaris ikut menjadi tersangka karena kurang hati-hati dalam menjalankan kewenangan jabatannya dalam membuat akta.

3. Kurangnya pengawasan kode etik notaris dalam menjalankan kewenanganya jabatannya

Kode etik profesi adalah seperangkat kaedah, baik tertulis maupun tidak tertulis, yang berlaku bagi anggota organisasi profesi yang bersangkutan. Ikatan Notaris Indonesia (INI) merupakan satu-satunya organisasi profesi yang diakui keberadaannya sesuai dengan dengan Pasal 83 ayat 1 UUJN. Notaris yang menjalankan profesi, wajib tunduk pada suatu peraturan yang bersifat internal yang berlaku dalam suatu organisasi profesi tertentu. Selain itu, kode etik notaris juga berperan penting sebagai sarana kontrol sosial. ${ }^{11}$

Dalam menjalankan jabatannya seorang notaris tidak pernah lepas dari kewajiban yang harus dipenuhi serta untuk memaksimalkan kinerjanya. Adapun kewajiban seorang Notaris sebagaimana yang disebut dalam Pasal 16 UUJN-P, yaitu bahwa seorang notaris harus bertindak jujur, seksama, mandiri, tidak berpihak, dan menjaga kepentingan pihak yang terkait dalam perbuatan hukum. Selain itu seorang notaris juga wajib membuat akta dalam bentuk minuta akta dan menyimpannya sebagai bagian dari protokol notaris.

MKN merupakan organ perlengkapan INI yang terdiri dari anggotaanggota yang dipilih dari anggota INI dan werda notaris, yang berdedikasi 2006), hal. 56 .
67

${ }^{11}$ Abdulkadir Muhammad, Etika Profesi Hukum, (Bandung: Citra Aditya Bakti, 
tinggi dan loyal terhadap perkumpulan, berkepribadian baik, arif dan bijaksana, sehingga dapat menjadi panutan bagi anggota dan diangkat oleh kongres untuk masa jabatan yang sama dengan masa jabatan kepengurusan. MKN berwenang melakukan pemeriksaan atas pelanggaran terhadap kode etik dan menjatuhkan sanksi kepada pelanggarnya sesuai dengan kewenangannya dan bertugas untuk:

1. Melakukan pembinaan, bimbingan, pengawasan, pembenahan anggota dalam menjunjung tinggi kode etik;

2. Memeriksa dan mengambil keputusan atas dugaan pelanggaran ketentuan kode etik yang bersifat internal atau yang tidak mempunyai masyarakat secara Iangsung;

3. Memberikan saran dan pendapat kepada majelis pengawas atas dugaan pelanggaran kode etik dan jabatan notaris.

Keberadaan MKN sebagai institusi yang melakukan pembinaan terhadap Notaris Sejak diundangkannya Undang-Undang Nomor 2 Tahun 2014 Tentang Perubahan Atas Undang-Undang Nomor 30 Tahun 2004 Tentang Jabatan Notaris, telah dibentuk lembaga perlindungan hukum baru yang bernama MKN (sebagaimana paparan diatas) yang bertugas melaksanakan pembinaan, bimbingan, pengawasan dan pembenahan anggota dalam rangka memperkuat institusi notaris dalam menjalankan amanah UUJN. Hal ini dapat dilihat dari maksud atau tujuan dibentuknya MKN sebagai suatu lembaga perlindungan hukum terhadap jabatan notaris.

Keberadaan (MKN) ini diatur dalam Pasal 66 A ayat (1) $\mathrm{UUJN}^{12}$ yang menyatakan, bahwa dalam melaksanakan pembinaan, Menteri membentuk MKN. Anggota dari Majelis MKN ini berjumlah 7 (tujuh) orang, yang terdiri atas unsur notaris sebanyak 3 (tiga) orang; Pemerintah sebanyak 2 (dua) orang; Ahli atau akademisi sebanyak 2 (dua) orang. Peran penting dari lembaga MKN ini adalah "menggantikan" peran Majelis Pengawas Daerah (MPD) dalam menyetujui atau menolak pemanggilan notaris dan pengambilan fotokopi protokol notaris oleh penyidik, penuntut umum dan hakim. MKN ini merupakan badan yang bersifat independen dalam mengambil keputusan yang mempunyai tugas dan kewajiban untuk memberikan bimbingan atau pembinaan dalam rangka memperkuat institusi notaris dalam menegakkan UUJN bagi setiap orang yang menjalankan jabatan sebagai notaris.

\section{PENUTUP}

${ }^{12}$ Undang-Undang Nomor 2 Tahun 2014 Tentang Perubahan Atas Undang-Undang Nomor 30 Tahun 2004 Tentang Jabatan Notaris 
Perlindungan hukum terhadap Notaris-PPAT dalam menjalankan kewenangan jabatannya terkait dengan pembuatan akta sangat rapuh walaupun sudah diatur dalam pasal 66 ayat 1 UUJN-P. Didalam faktanya jika seorang Notaris-PPAT melakukan malpraktek atau kurang teliti didalam proses penandatanganan para pihak yang hadir dalam pembuatan akta maka akan terjerat perkara hukum. Didalam perkara hukum ini NotarisPPAT ditetapkan sebagai tersangka karena menyalahgunakan kewenangan jabatannya pada Pasal 3 dan membantu memperkaya orang lain pada Pasal 2 ayat 1 Undang-Undang Tipikor. Walaupun secara tidak langsung melakukan tindak pidana korupsi, notaris bisa ditetapkan sebagai tersangka.

Ada 3 faktor yang membuat Notaris-PPAT bisa ditetapkan sebagai tersangka tindak pidana korupsi dalam menjalankan kewenangan jabatannya terkait dengan pembuatan akta yaitu kurangnya penerapan prinsip kehatihatian, kedekatan emosional antara Notaris-PPAT dengan para pihak (klien) dan kurangnya pengawasan kode etik notaris.

\section{KESIMPULAN}

\section{Buku}

Abdulkadir Muhammad.2006. Etika Profesi Hukum, Bandung: Citra Aditya Bakti.

Bambang Waluyo.2002. Penelitian Hukum dalam Praktek, Jakarta: Sinar Grafika.

Habib Adjie, 2014. Hukum Notaris di Indonesia, Bandung: PT Refika Aditama. , 2015. Penafsiran Tematik Hukum Notaris di Indonesia, PT Refika Aditama, Bandung.

Maria S.W. Sumardjono.2001. Kebijakan Pertanahan Antara Regulasi dan Implementasi,Jakarta: Kompas.

Soerjono Soekanto.1986. Pengantar Penelitian Hukum, Jakarta: Universitas Indonesia Press.

\section{Peraturan Perundang-undangan}

Peraturan Menteri Hukum dan Hak asasi Manusia Republik Indonesia Nomor 7 Tahun 2016 tentang Majelis Kehormatan Notaris Undang-Undang Nomor 30 tahun 2004 tentang Jabatan Notaris. Undang-Undang Nomor 2 Tahun 2014 tentang Perubahan Atas UndangUndang Nomor 30 Tahun 2004 Tentang Jabatan Notaris. 
TINDAK PIDANA KORUPSI YANG DILAKUKAN NOTARIS-PPAT DALAM MENJALANKAN

KEWENANGAN JABATANNYA (Agus Santoso)

Undang-Undang Nomor 31 Tahun 1999 tentang Pemberantasan Tindak Pidana Korupsi.

Undang-Undang Republik Indonesia Nomor 20 Tahun 2001 tentang Perubahan atas Undang-Undang Nomor 31 Tahun 1999 tentang Pemberantasan Tindak Pidana Korupsi.

\section{Internet}

http://wartahukum.net/2018/10/notaris-natalia-christiana-akhirnyaditetapkan-sebagai-tersangka/, Diakses pada tanggal 22 Nopember 2018, jam 22.45 WIB. 